\title{
Current Alternations in Inflection of Polish Masculine Inanimate Nouns in the Singular: A Pilot Study
}

\author{
Hanna Mausch \\ Institute of Linguistics, Adam Mickiewicz University \\ ul. Międzychodzka 5, 60-371 Poznań, POLAND \\ hmausch@yahoo.com
}

\begin{abstract}
This paper discusses current use of genitive and accusative case forms of common nouns borrowed from English that are increasingly present in Polish and identified as masculine inanimate by virtue of their consonantal offsets in the nominative singular (bare forms).

In the first part, an overview of approved usage is presented. That is, a survey the assignment of nouns to various inflectional patterns based on works of three acclaimed Polish linguists is offered. In the second part, a pilot study involving a test given to Polish students is discussed. Finally, standard patterns are compared to the actual usage of the nouns tested. The objective is to identify regularities in the assignment of case endings. Results of this pilot study are to be treated as hints for further research on current alternations in case forms.
\end{abstract}

\section{Overview}

In Modern Polish, nouns follow a number of declensions. Two tendencies can be observed: genitive forms are increasingly used in the accusative case and, somewhat less often, accusative forms are used in the genitive case. These alternations are common in both numbers, singular and plural, however in the singular paradigms, these developments are most striking. ${ }^{1}$ In the singular, there are three basic patterns; there are masculine, feminine and neuter declensions. ${ }^{2}$ Almost all masculine nouns ${ }^{3}$ in the nominative singular end in a consonant. This nominative form is also used as the accusative form of masculine inanimate nouns. Masculine animate nouns have distinctive nominative forms whereas their genitive and accusative forms are identical and end in $-a{ }^{4}$ The genitive endings of inanimate nouns are $-a$ and $-u$. Common nouns

\footnotetext{
The content of this paper owes much to Michael Farris whose detailed scrutiny and criticisms were most useful.

1 In plural the main division is between [+virile] pattern that is the inflectional pattern of nouns denoting male humans and the [-virile] declension. The chief difference between the patterns is that in the [+virile] pattern genitive forms have replaced the old accusative forms whereas in the [-virile] pattern the genitive and accusative forms do differ. This difference between the patterns refers to personal, demonstrative, relative and possessive pronouns as well as to adjectives. Actually, genitive pronoun and adjective forms are the same in both patterns. The [+/- virile] contrast is supported by two distinct forms of verbs in the past tense.

2 See http://sjp.pwn.pl/odmiany for example.

3 Minor declensions are not discussed since their patterns are not productive.

${ }^{4}$ Pronouns and adjectives follow the same patterns. Past tense verb forms have three distinct endings: masculine, feminine and neuter in the singular.
} 
borrowed from English are increasingly present in Polish and identified as masculine inanimate by virtue of their consonantal offsets in the nominative singular (bare forms).

In standard grammar books, the characteristic feature of inanimate paradigms is nominative accusative syncretism, and genitive - accusative syncretism is treated as an exception to the "rule". Increasingly, however, masculine inanimate nouns take $-a$ in the genitive and this form is used in the direct object function.

Direct objects are in the accusative case, however, if under negation, the genitive case forms are used instead. Thus the case of a direct object depends on whether the verb is negated or not. This use of case forms can be exemplified as follows:

ANIMATE

Mam syna.

I have a son.

Nie mam syna.

I do not have a son.
Mam psa.

I have a dog.

Nie mam psa.

I do not have a dog.
INANIMATE

Mam komputer.

I have a PC.

Nie mam komputera.

I do not have a PC.

\subsection{Inflectional paradigms: Klemensiewicz, Doroszewski and Grzegorczykowa}

Problems with the inflection of masculine inanimate nouns are mentioned in most books on Polish grammar. They are discussed at length by three acclaimed grammarians: Klemensiewicz's history of Polish grammar (1981), Doroszewski's dictionary of correct Polish (1980) and Grzegorczykowa's book on Polish modern morphology (1998). In these books, groups of nouns that take $-a$ and $-u$ in the genitive and syncretisms are identified and borrowings are identified as a separate group. ${ }^{5}$

\subsection{Genitive forms}

In all these books, nouns that take $-a$ or/and $-u$ in the genitive are grouped mostly according to the meanings of the nouns. Groupings according to morphological and phonological structures are much less numerous. All authors identify borrowings as a group of nouns that take $-u$ in the genitive, however, they also give borrowed nouns as examples typical for other noun groups including some that take $-a$ in the genitive.

Actually, the choice of genitive forms is often troublesome for native speakers of Polish. In another book by Klemesiewicz entitled Podstawowe wiadomości z gramatyki języka polskiego [Essentials of the grammar of the Polish language] (1962: 72), he comments on the use of masculine genitive endings as follows: "Użycie końcówki $-a$ lub $-u$ zależy właściwie od zwyczaju, a wskaźnikiem jest poczucie językowe. Zaledwie co do kilku grup można podać bliższe wskazówki [...]"6. Doroszewski (1980: 122) writes that the assignment of $-a$ and $-u$ does not follow any clear rules and often both can be used, however $-u$ is rarer than $-a$. Grzegorczykowa (1998: 306) writes that $-u$ is a characteristic ending of the genitive case of [-animate] nouns but it is not obligatory; the other "parallel" ending is $-a$. The choice ("repartition of endings") is conditioned by "lexical factors". She adds that some regularities can, nevertheless, be observed and they "are dependent on the meaning or morphological structure of nouns". These regularities, according to Grzegorczykowa, are tendencies, not rules. All authors mention exceptions.

In the GENITIVE and ACCUSATIVE tables below, groupings offered by the three authors are collated. $^{7}$

\footnotetext{
${ }^{5}$ For a detailed study on Polish grammatical gender see Kucała (1978).

${ }^{6}$ "The use of the ending -a and -u actually depends on custom and the indicator is language intuition. Only for few groups some indications can be offered [...]."

${ }^{7}$ Actually, the authors use various cover names or descriptions for the groups and the "contents" of groups may differ too.
} 
Table 1. - u GENITIVES [+masculine, -animate]

\begin{tabular}{|c|c|c|}
\hline KLEMENSIEWICZ & DOROSZEWSKI & GRZEGORCZYKOWA \\
\hline borrowings & + & + \\
\hline "umysłowe" (mental) & + abstract nouns & $\begin{array}{c}+ \text { (abstract and "czynnościowe", } \\
\text { i.e. referring to activities })\end{array}$ \\
\hline collective & + & + \\
\hline \multirow[t]{5}{*}{ "materialne" (substances, mass) } & + & $+($ uncountable $)$ \\
\hline & & + \\
\hline & & ending in-unek \\
\hline & & $\begin{array}{l}\text { members of homonymic pairs } \\
\text { that do not refer to persons }\end{array}$ \\
\hline & & some proper nouns \\
\hline
\end{tabular}

As far as borrowings are concerned, Klemensiewicz (1981: 268) offers the following examples:

N. teatr $^{8}$ (E. theatre), G. teatru

N. regulamin (E. rules and regulations), G. regulaminu

N. alarm (E. alarm), G. alarmu.

Doroszewski's examples of borrowing are listed in the entry dopetniacz (E. genitive) (1980: 122) and in addition to teatr include:

N. puder (E. cosmetic powder), G. pudru

N. ksztatt (E. shape), G. kształtu

N. dach (E. roof), G. dachu.

Grzegorczykowa (1998 : 307) offers the following examples:

N. impas (E. impasse), G. impasu

N. heksametr (E. hexameter), G. heksametru

N. marsz (E. a march), G. marszu

N. tampon (E. tampon), G. tamponu

N. tramwaj (E. tram, tramcar), G. tramwaju

N. hotel (E. hotel), G. hotelu?

She also writes that all nouns ending in the nominative in -izm (all of them borrowed) take $-u$ in the genitive, e.g. N. pedantyzm (E. pedantry), G. pedantyzmu, N. neologizm (E. neologism), G. neologizmu.

It goes without saying that to most of these groups some borrowed nouns also belong, e.g.

N. komputer (E. computer), G. komputera;

N. dolar (E. dollar), G. dolara;

N. ford (E. ford, a car), G. forda;

N. tenis (E. tennis), G. tenisa;

N. fokstrot (E. foxtrot), G. fokstrota.

\footnotetext{
${ }^{8}$ As offsets of nominatives are discussed later, their forms are given here in addition to genitives.

${ }^{9}$ At this point, however, she notices that $-a$ is the genitive ending of e.g. helikopter (E. helicopter), parasol (E. umbrella); see also - $a$ genitives below.
} 
Table 2. -a GENITIVES [+masculine, - animate]

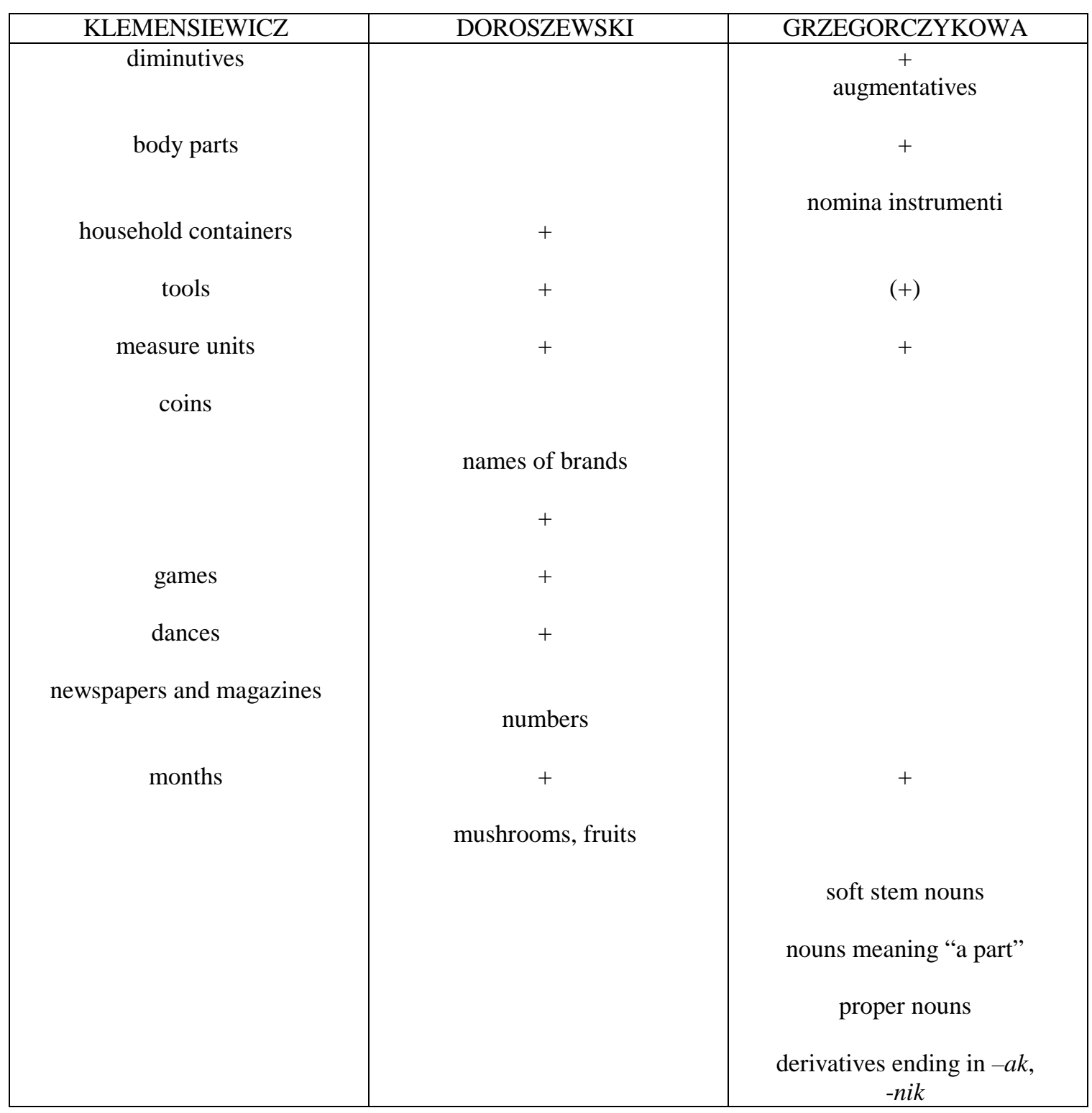

\subsection{Accusative forms}

Occasionally, the choice of an accusative form is also troublesome. Masculine inanimate nouns are said to have the accusative form identical with their nominative form. This, however, is not always the case although none of Polish dictionaries consulted offers alternative accusative endings in tables presenting inflectional patterns.

All the aforementioned authors notice that genitive forms of masculine inanimate nouns are occasionally used where accusative / nominative forms are expected. Klemensiewicz (1981: 272) observes that genitive forms of some [-animate] nouns are increasingly used as accusative forms. Doroszewski's entry biernik (E. accusative) (1981: 43 - 4) reads in 3. that in addition to [+animate, +masculine] nouns, accusative and genitive forms of other types of nouns are also identical, meaning that $-a$ is their ending. Grzegorczykowa (1998: $300-1)$ mentions genitive/accusative syncretism of some [-animate] noun forms while introducing declinations of [+masculine, +animate] nouns. She writes that for a [-animate] noun to join the [+animate] category, its genitive ending $-u$ needs to be changed to $-a$ as well. If a noun e.g. sport takes $-u$ 
in the genitive (this form refers to an activity) and $-a$, which refers to a name of cigarettes, two lexemes are born that are homonymous: one is [-animate] and the other is [+animate]. She observes that the group of grammatically [+animate] nouns keeps growing.

Table 3. - a ACCUSATIVES of [-animate] nouns

\begin{tabular}{|c|c|c|}
\hline KLEMENSIEWICZ & DOROSZEWSKI & GRZEGORCZYKOWA \\
\hline & + & $+(-)^{10}$ \\
dances & + & + \\
games & + & + \\
coins & dead and supernatural person & + \\
cigarettes & + & + (monetary units $)$ \\
& cars & \\
& + & mushrooms \\
& + & \\
\hline
\end{tabular}

Actually, dolar, ford, and fokstrot have - $a$ in both, the genitive and the accusative.

\subsection{Summary}

From the above it follows that [-animate] nouns often take $-a$ in the genitive alongside [+animate] nouns. The consonantal offsets of these [-animate] nouns can be very different. It also follows that [-animate] nouns that have $-a$ genitives can also have $-a$ accusatives, e.g.

Widzęananasa $i$ ogórek.

I see a pineapple [accusative $=$ genitive] and a cucumber [accusative $=$ nominative]

Nie widze ananasa ani ogórka.

I do not see a pineapple [genitive] nor a cucumber [genitive]

\section{Test}

A diagnostic test was designed to check forms of 46 borrowed masculine inanimate nouns used by 32 freshmen in the Institute of Linguistics at Adam Mickiewicz University, Poznan (January 2002). The students knew English (elementary to advanced levels).

In this pilot study, old and new borrowings were tested. Some tested nouns are part of everyday vocabulary and some are technical or scientific words.

Forty-four nouns were direct objects and 12 of them were used in negated sentences. Two nouns were used after preposition $d o$ which is followed by the genitive case forms. Two nouns - skaner and sonar - were used as direct objects of the verb $u \dot{z} y c$ (E. to use) that requires the direct object in the genitive case. Their nominative (bare) forms were provided and the students were asked to decide whether they use a bare form, a $-u$ form or an $-a$ form in each of the test sentences. They could give several forms if they used them, add a form in brackets indicating that they do not use it but are familiar with it and to give no form if they felt unsure or did not know a word. Forms of the following nouns were tested:

${ }^{10}$ She does not list "supernatural persons." 
Genitives of direct objects in negated sentences:

- smecz, kondom, bestseller, katamaran, keks, toster, walkower, casting, cheddar, display, pulsar, baseball

- after preposition $d o$ : terminal, tiebreak

- direct objects of the verb $u \dot{z} y c ́$ (E. to use): skaner, sonar

Accusatives of direct objects:

- airbus, chip, drink, kolt, flamaster, flesz, ful, grill, hamburger, gokart, grejpfrut, jeep, klaps, krakers, laser, poker, replay, sedan, set, squash, szlem, tenis, thriller, tuner, walkman, algol, catering, drajw, komp, pickup

\subsection{Test sentences}

For convenience, the sentences reproduced below have been numbered and translations provided.

\begin{tabular}{|c|c|}
\hline $\begin{array}{l}\text { 1. Nie widziała mojego smecz..... } \\
\text { She did not see my smash. }\end{array}$ & $\begin{array}{l}\text { 2. Nie miał kondom....... } \\
\text { He did not have a condom. }\end{array}$ \\
\hline $\begin{array}{l}\text { 3. Widzieliśmy airbus........... } \\
\text { We saw an airbus. }\end{array}$ & $\begin{array}{l}\text { 4. Nie czytałam tego bestseller......... } \\
\text { I did not read this bestseller. }\end{array}$ \\
\hline $\begin{array}{l}\text { 5. Podaj mi chip........ } \\
\text { Pass me the chip. }\end{array}$ & $\begin{array}{l}\text { 6. Chcesz drink.............? } \\
\text { Would you like a drink? }\end{array}$ \\
\hline $\begin{array}{l}\text { 7. Wyjął kolt...... } \\
\text { He pulled out his colt. }\end{array}$ & $\begin{array}{ll}\text { 8. } & \text { Daj flamaster......... } \\
& \text { Give me a felt-tip pen. } \\
& \text { [flamaster }<\text { E. Flowmaster] }\end{array}$ \\
\hline $\begin{array}{l}\text { 9. On ma flesz........ } \\
\text { He has got a flash lamp. }\end{array}$ & $\begin{array}{l}\text { 10. Ona ma ful....... } \\
\text { She has a full house. }\end{array}$ \\
\hline $\begin{array}{l}\text { 11. Podaj grill..... } \\
\text { Fetch the grill. }\end{array}$ & $\begin{array}{l}\text { 12. Zjem hamburger........... } \\
\text { I will eat a hamburger. }\end{array}$ \\
\hline $\begin{array}{l}\text { 13. Widzę gokart............ } \\
\text { I see a go-kart. }\end{array}$ & $\begin{array}{l}\text { 14. Zjedz grejpfrut............ } \\
\text { Eat a grapefruit. }\end{array}$ \\
\hline $\begin{array}{l}\text { 15. Kupie jeep........ } \\
\text { I will buy a jeep. }\end{array}$ & $\begin{array}{l}\text { 16. Nie widzieliśmy katamaran.......... } \\
\text { We did not see the catamaran. }\end{array}$ \\
\hline $\begin{array}{l}\text { 17. Nie ma już keks........... } \\
\text { There is no more fruitcake. } \\
\text { [keks < E. cakes] }\end{array}$ & $\begin{array}{l}\text { 18. Dał mi klaps.......... } \\
\text { He gave me a spank. } \\
\text { [klaps < E. clap] }\end{array}$ \\
\hline $\begin{array}{l}\text { 19. Chcesz krakers........? } \\
\text { Do you want a cracker (biscuit)? }\end{array}$ & $\begin{array}{l}\text { 20. Widzisz laser...........? } \\
\text { Do you see a/the laser? }\end{array}$ \\
\hline $\begin{array}{l}\text { 21. Lubię poker.......... } \\
\text { I like poker. }\end{array}$ & $\begin{array}{l}\text { 22. Oglądał replay......... } \\
\text { He watched a replay. }\end{array}$ \\
\hline $\begin{array}{l}\text { 23. Kupił sedan........ } \\
\text { He bought a sedan (car). }\end{array}$ & $\begin{array}{l}\text { 24. Wygrali set.......... } \\
\text { They won the set (tennis, } \\
\text { valleyball). }\end{array}$ \\
\hline $\begin{array}{l}\text { 25. Użyj skaner......... } \\
\text { Use the scanner. }\end{array}$ & $\begin{array}{l}\text { 26. Lubię squash............... } \\
\text { I like squash. }\end{array}$ \\
\hline $\begin{array}{l}\text { 27. Zrobił szlem......... } \\
\text { He made a grand slam (bridge). }\end{array}$ & $\begin{array}{l}\text { 28. Lubię tenis......... } \\
\text { I like tennis }\end{array}$ \\
\hline $\begin{array}{l}\text { 29. Muszę dojść do terminal.............. } \\
\text { I must reach the terminal. }\end{array}$ & $\begin{array}{l}\text { 30. Oglądał thriller........ } \\
\text { He watched a thriller. }\end{array}$ \\
\hline $\begin{array}{l}\text { 31. Doszło do tie-break........... } \\
\text { It came to a tie-break. }\end{array}$ & $\begin{array}{l}\text { 32. Nie mam toster............ } \\
\text { I do not have a toaster. }\end{array}$ \\
\hline $\begin{array}{l}\text { 33. Dostałeś tuner..........? } \\
\text { Did you get the tuner? }\end{array}$ & $\begin{array}{l}\text { 34. Masz walkman...........? } \\
\text { Have you got a walkman? }\end{array}$ \\
\hline $\begin{array}{l}\text { 35. Nie było walkower........... } \\
\text { There was no walkover. }\end{array}$ & $\begin{array}{l}\text { 36. Znam algol........... } \\
\text { I know ALGOL. }\end{array}$ \\
\hline $\begin{array}{l}\text { 37. Nie było casting......... } \\
\text { There was no casting (TV). }\end{array}$ & $\begin{array}{l}\text { 38. Zorganizował catering.......... } \\
\text { He organized the catering. }\end{array}$ \\
\hline $\begin{array}{l}\text { 39. Nie mam cheddar............ } \\
\text { I have no cheddar. }\end{array}$ & $\begin{array}{l}\text { 40. Nie widział jej display......... } \\
\text { He did not see her display } \\
\text { (computer). }\end{array}$ \\
\hline
\end{tabular}




\begin{tabular}{|c|c|}
\hline $\begin{array}{l}\text { 41. Masz ich drajw........? } \\
\text { Do you have their drive } \\
\text { (computer)? }\end{array}$ & $\begin{array}{l}\text { 42. Masz komp.........? } \\
\text { Have you got a CD/ a computer? }\end{array}$ \\
\hline $\begin{array}{l}\text { 43. Nie dostrzegł pulsar.............. } \\
\text { He did not spot the pulsar. }\end{array}$ & $\begin{array}{l}\text { 44. Możesz użyć sonar.......... } \\
\text { You can use a/the sonar. }\end{array}$ \\
\hline $\begin{array}{l}\text { 45. Nie lubię baseball............ } \\
\text { I do not like baseball. }\end{array}$ & $\begin{array}{l}\text { 46. Kup mi pikup............. } \\
\text { Buy me a pickup. }\end{array}$ \\
\hline
\end{tabular}

\subsection{Expected case forms}

Noun entries were originally checked in 5 dictionaries: Maty stownik języka polskiego [Small dictionary of the Polish language, henceforth MSJP] (Skorupka, Auderska, Łempicka, 1968), Stownik poprawnej polszczyzny [Dictionary of the correct Polish, henceforth SPP] (Doroszewski 1980), Nowy stownik poprawnej polszczyzny [New dictionary of the correct Polish, henceforth NSPP] (Markowski 1999), Stownik wspótczesnego języka polskiego [Dictionary of contemporary Polish language, henceforth SWJP] (1998) and Inny Stownik Języka Polskiego PWN [A Different Dictionary of the Polish Language, henceforth ISJP] (Bańko: 2000). In 2003, dictionaries on a CDROM released by PWN were consulted (Stowniki PWN: Stownik języka polskiego, Stownik ortograficzny, Stownik wyrazów obcych, Stownik poprawnej polszczyzny, [Dictionaries PWN: Dictionary of Polish language, Spelling dictionary, Dictionary of foreign words, Dictionary of proper Polish] 2003, version 1.1, henceforth CD).

In the first parts of the dictionaries, declension paradigms are given. MSJP, SPP, NSPP and $\mathrm{CD}$ present 5 masculine paradigms. According to first four, inanimate nouns are declined. In MSJP, SPP and CD, inanimate nouns in the singular have $-a$ in the genitive and the accusative form identical to the nominative. In NSPP, the tables with inflectional patterns "give inflectional forms of a noun that are not given in the entries" (p. xxxii). In the case of masculine nouns in the singular, these are $-a$ in the genitive and information that they have accusative forms identical with their nominative forms. ${ }^{11}$ In SPP, offsets of nouns are the criterion for assigning them to inflectional patterns and since MSJP, NSPP and CD have the same patterns a shortened version ${ }^{12}$ of SPP patterns (Doroszewski 1980: xxvi - xxvii) is presented below.

Table 4. Inflectional patterns

\begin{tabular}{|c|c|c|c|c|c|}
\hline & \multirow[b]{2}{*}{ CASE } & I & II & III & IV \\
\hline & & $\begin{array}{c}<\dot{c}, \text { dź, j, ń, ś, } \\
\text { ź>, }<\mathrm{l}>,<p, b, \\
\text { m, w> }\end{array}$ & $\begin{array}{l}\langle\mathrm{c}, \mathrm{cz}, \mathrm{dz}, \mathrm{d} \dot{\mathrm{z}}, \\
\quad \mathrm{rz}, \mathrm{sz}, \mathrm{z}>\end{array}$ & $\langle\mathrm{k}, \mathrm{g}, \mathrm{ch}\rangle$ & $\begin{array}{c}\langle\mathrm{b}, \mathrm{d}, \mathrm{t}, \mathrm{m}, \mathrm{n}, \mathrm{p} \\
\mathrm{r}, \mathrm{s}, \mathrm{t}, \mathrm{w}, \mathrm{z}>\end{array}$ \\
\hline \multirow{6}{*}{$\begin{array}{l}\mathrm{S} \\
\mathrm{I} \\
\mathrm{N} \\
\mathrm{G} \\
\mathrm{U} \\
\mathrm{L} \\
\mathrm{A} \\
\mathrm{R}\end{array}$} & Nom. & $\varnothing$ & $\varnothing$ & $\varnothing$ & $\varnothing$ \\
\hline & Gen. & $-a$ & $-\mathrm{a}$ & $-a$ & $-\mathrm{a}$ \\
\hline & Dat. & -owi & -owi & -owi & -owi \\
\hline & $\begin{array}{l}\text { Acc. } \\
\text { An. } \\
\text { In. }\end{array}$ & $\begin{array}{l}=\text { Gen. } \\
=\text { Nom. }\end{array}$ & $\begin{array}{l}=\text { Gen. } \\
=\text { Nom. }\end{array}$ & $\begin{array}{l}=\text { Gen. } \\
=\text { Nom. }\end{array}$ & $\begin{array}{l}=\text { Gen. } \\
=\text { Nom. }\end{array}$ \\
\hline & Inst. & -em & -em & -(i)em & -em \\
\hline & Loc. & $-\mathrm{u}$ & $-\mathrm{u}$ & $-\mathrm{u}$ & $-\mathrm{u}$ \\
\hline
\end{tabular}

- To Group I, nouns that end in phonetically soft consonants (palatalized) and /l/ belong as well as nouns that end in <p, b, w> replaced by /p', b', m', w'/ [palatalized] in dependent cases.

- To Group II, nouns that end in functionally soft consonants belong.

- To Group IV, nouns ending in hard consonants belong.

\footnotetext{
${ }^{11}$ See patterns presented at http://sjp.pwn.pl/odmiany.

${ }^{12}$ Examples are omitted.
} 
ISJP gives "rules for forming noun forms" (p. L). Three masculine patterns are given: [+virile], [-virile, +animate $]^{13}$ and inanimate. No rule is offered for genitive forms, instead their endings are given in the entries. The rule for forming the accusatives of inanimate nouns reads that they are identical with their nominative forms $(X \rightarrow X)$.

SWJP offers separate groups of inflectional patterns for masculine [+virile], masculine animate and masculine inanimate nouns. There are three groups of paradigms for inanimate nouns and each of them has 2 or 3 sub-paradigms. All together the nouns can follow 8 inanimate patterns and one pattern of masculine animate nouns (p. xiv). Some patterns have $-a$ and some $-u$ genitives. On p. xiii, it reads that the masculine animate and inanimate genders are established on the basis of formal criteria only (not semantic characteristics) ${ }^{14}$. This formal criterion for masculine animate gender is the accusative - genitive syncretism in the singular and for the masculine inanimate gender it is the nominative - accusative syncretism. It follows that semantically inanimate nouns may be formally animate.

In all dictionaries consulted, genitive singular forms of masculine inanimate nouns are given in the entries as a rule and occasionally accusative singular forms are given too. ${ }^{15}$ This practice "corresponds" to problems Poles might have with the forms in question.

MSJP lists 14 nouns $^{16}$ of the 46 nouns tested, SPP lists 15 nouns, NSPP lists 31 nouns, SWJP lists 35 nouns, and ISJP lists 37 nouns. ISJP is actually the first learners' dictionary on the market. CD lists 43 nouns. Numbers of entries demonstrate that borrowings from English are increasingly present in Polish. The spellings of nouns tested may vary. In the table below, the test forms are reproduced which, as it has happened, are identical to $\mathrm{CD}$ spellings. In the table, $\mathbf{S}$ stands for structure, $\mathbf{N}$ for negation and do marks sentences with this preposition. All relevant information provided in the entries is included. In stands for inanimate and An for animate (their genitive forms are used as accusative forms, i.e. they end in $-a$ ). Roman numbers are the numbers of inflectional paradigms. Genitive endings in brackets are rarer forms; accusative forms in brackets alternate with nominative (bare) forms. If no accusative ending is given and the noun is not marked as animate, its accusative form is identical to the nominative.

In the oldest dictionary, only 14 nouns are listed and in the most recent dictionary as many as 42 are listed. Of the nouns checked, only two are not listed in any dictionary, i.e. (38) catering and (42) komp. (38) is definitely used in Polish; (42) is very colloquial.

If an accusative form of a listed noun was not given, it was assumed that the form was identical to the nominative form and the noun was inanimate. Consequently, according to dictionaries, nouns listed as $1-4,8-9,11,16-17,20,22-23,29-33,35-36,39-41,43$, $45-46$ are inanimate whereas $5-7,12,14-15,18-19,24-25,26-28,44$ are grammatically or formally animate. The least clear case is 10 as each of its two entries gives different information. In the remaining cases, it was assumed that the prevailing identification was more widely accepted and thus 13 was accepted to be inanimate and 21 and 34 were accepted to be animate.

Considering the tested nouns, their number in dictionaries more than tripled in 35 years. The number of grammatically animate nouns has also grown. In MSJP only 1 noun follows an animate declension, in SPP 3 nouns, in NSPP 8, in SWJP 8 (+1 In/An), in ISJP 14 (+2 In/An, $\mathrm{An} / \mathrm{In})$ and on CD 12 nouns are animate. Although $-u$ genitives are said to be common with borrowings, in ISJP and on CD, $-u$ genitives are rare. In ISJP only 2 nouns are assigned $-u$ and 4 $a /-u$ and on $\mathrm{CD}, 8$ nouns have $-u$ genitives and 11 have $-a /-u$ genitives.

\footnotetext{
${ }^{13}$ The word used is męskozwierzęce, i.e masculine [+animal].

14 „Rodzaj męskożywotny lub męskonieżywotny ustala się wyłącznie na podstawie kryterium formalnego [....] a nie właściwości semantycznych".

${ }^{15}$ Genitive and accusative forms of other nouns in the singular are given rarely, virtually only if the structure of a noun stem changes e.g. N. osiot (E, donkey), G. osta or if there might be some problems with the spelling.

${ }^{16}$ Occasionally though, the required meanings are not included in the noun entry. For details see footnotes to the table below.
} 
Table 5. Dictionary entries of the nouns tested

\begin{tabular}{|c|c|c|c|c|c|c|c|c|}
\hline No & Noun & S & $\begin{array}{c}\text { MSJP } \\
1968\end{array}$ & $\begin{array}{l}\text { SPP } \\
1980\end{array}$ & $\begin{array}{c}\text { NSPP } \\
1999\end{array}$ & $\begin{array}{c}\text { SWJP } \\
1998 \\
(1996) \\
\end{array}$ & $\begin{array}{l}\text { ISJP } \\
2000\end{array}$ & $\begin{array}{c}C D \\
2003\end{array}$ \\
\hline 1 & smecz & $\mathrm{N}$ & II G -u & - & II G -u & In III G -u & In G -u & II G -u \\
\hline 2 & kondom & $\mathrm{N}$ & - & - & IV G -u & In I G -u & In $G-u$ & IV G -u \\
\hline 3 & airbus & & - & - & - & $\begin{array}{c}\text { In I G -u } \\
\text { aerobus }\end{array}$ & $\begin{array}{l}\text { In } \mathrm{G}-\mathrm{a} \\
\text { aerobus }\end{array}$ & $\mathrm{G}-\mathrm{a} /-\mathrm{u}$ \\
\hline 4 & bestseller & $\mathrm{N}$ & $\begin{array}{c}\text { IV }^{17} \\
\text { bestseler }\end{array}$ & $\begin{array}{c}\text { IV G -a } \\
(-\mathrm{u})\end{array}$ & $\begin{array}{c}\text { IV G -a } \\
(-u)\end{array}$ & $\begin{array}{c}\text { In I G } \\
-\mathrm{a} /-\mathrm{u}\end{array}$ & In $\mathrm{G}-\mathrm{a}$ & IV G -a/-u \\
\hline 5 & chip & & - & - & - & - & An $\mathrm{G}-\mathrm{a}$ & $G-a^{18}$ \\
\hline 6 & drink & & - & - & III G/A -a & An IIa & An $\mathrm{G}-\mathrm{a}$ & III G/A -a \\
\hline 7 & kolt & & IV & - & IV G/A -a & $? \mathrm{~m} \mathrm{I}^{19}$ & An G -a & IV G/A -a \\
\hline 8 & flamaster $^{20}$ & & - & - & IV G -a & In I G -a & In $\mathrm{G}-\mathrm{a}$ & IV G -a \\
\hline 9 & flesz & & II G -u & II G -a/-u & II. $\mathrm{G}-\mathrm{a} /-\mathrm{u}$ & $\begin{array}{c}\text { In III G } \\
-\mathrm{a} /-\mathrm{u}\end{array}$ & In $\mathrm{G}-\mathrm{a}$ & II G -a/-u \\
\hline 10 & ful & & - & - & - & - & An $G-a$ & I G -a \\
\hline 11 & grill & & - & - & I G -a & In III G -a & In $\mathrm{G}-\mathrm{a}$ & I G -a \\
\hline 12 & hamburger & & - & - & IV G/A -a & An I & An $\mathrm{G}-\mathrm{a}$ & IV G/A -a \\
\hline 13 & gokard & & - & IV G -a & IV G -a & In I G -a & An $\mathrm{G}-\mathrm{a}$ & IV G -a/-u \\
\hline 14 & grejpfrut & & IV & IV G -a & $\begin{array}{c}\text { IV G -a } \\
\text { A (-a) }\end{array}$ & $\begin{array}{c}\text { In I In/An } \\
\text { G -a }\end{array}$ & $\begin{array}{c}\text { An } \mathrm{G}-\mathrm{a} \\
/ \mathrm{In}\end{array}$ & $\begin{array}{c}\text { IV G -a } \\
\text { A (-a) }\end{array}$ \\
\hline 15 & jeep & & - & IV G -a & IV G/A -a & An I dżip & An G -a & IV G/A -a \\
\hline 16 & katamaran & $\mathrm{N}$ & - & IV G -a/-u & IV G -a/-u & In I G -a/u & In $\mathrm{G}-\mathrm{a} /-\mathrm{u}$ & IV G -a/-u \\
\hline 17 & keks & $\mathrm{N}$ & IV G -u & IV G -u/-a & IV $\mathrm{G}-\mathrm{u} / \mathrm{-a}$ & In I G -u/a & In $\mathrm{G}-\mathrm{u} / \mathrm{-a}$ & IV G -a/-u \\
\hline 18 & klaps & & $\operatorname{IV}(A-a)^{21}$ & IV G/A -a & IV G/A -a & An I & An $\mathrm{G}-\mathrm{a}$ & IV G/A -a \\
\hline 19 & krakers & & - & - & IV G/A -a & An I G -a & An $\mathrm{G}-\mathrm{a}$ & IV G/A -a \\
\hline 20 & laser & & IV & - & IV G -a & In I G -a & In $\mathrm{G}-\mathrm{a}$ & IV G -a \\
\hline 21 & poker & & IV & IV G/A -a & IV G/A -a & In I G -a & An $\mathrm{G}-\mathrm{a}$ & IV G/A -a \\
\hline 22 & replay & & - & - & I G -u/-a & In III G -a & In $\mathrm{G}-\mathrm{a} / \mathrm{-u}$ & I G -u/-a \\
\hline 23 & sedan & & - & & - & - & In $\mathrm{G}-\mathrm{a}$ & $\mathrm{G}-\mathrm{u}$ \\
\hline 24 & set & & IV & IV G/A -a & $\begin{array}{c}\text { IV G -a } \\
\text { A (-a) }\end{array}$ & An I & An $\mathrm{G}-\mathrm{a}$ & $\begin{array}{c}\text { IV G -a } \\
\text { A (-a) }\end{array}$ \\
\hline 25 & skaner & to use & - & - & - & In I G -a & In $\mathrm{G}-\mathrm{a}$ & $\mathrm{G}-\mathrm{a}$ \\
\hline 26 & squash & & - & - & - & - & An $G-a$ & - \\
\hline 27 & szlem & & IV & IV G -a (u) & IV G/A -a & $\begin{array}{c}\text { An I G -a/- } \\
u \\
A-a \\
\end{array}$ & An G-a & $\begin{array}{l}\text { IV G -a } \\
(-\mathrm{u}) \mathrm{A}-\mathrm{a}\end{array}$ \\
\hline 28 & tenis & & IV & $\mathrm{IV}^{22} \mathrm{G}-\mathrm{a}$ & $\begin{array}{c}\text { IV G -a } \\
\text { A (-a) }\end{array}$ & An I & $\mathrm{In} / \mathrm{An} \mathrm{G}-\mathrm{a}$ & $\begin{array}{c}\text { IV G -a } \\
\text { A (-a) }\end{array}$ \\
\hline 29 & terminal & do & - & - & I G -u (a) & In III G -a & $\begin{array}{c}\text { In G-u } \\
(-a)\end{array}$ & I G -u (-a) \\
\hline 30 & thriller & & - & - & IV G -a & In I G -a & In $G-a$ & IV G -a \\
\hline 31 & tie-break & do & - & - & III G -u & In IIa G -a & In G-a & $\begin{array}{c}\text { III G -a } \\
\text { III G - } \text { u }^{23}\end{array}$ \\
\hline 32 & toster & $\mathrm{N}$ & - & - & IV G -a & In I G -a & In G-a & IV G -a \\
\hline 33 & tuner & & - & - & IV G -a & In I G -a & In $\mathrm{G}-\mathrm{a}$ & IV G -a \\
\hline 34 & walkman & & - & - & $\begin{array}{c}\text { IV G -a -A } \\
(-a)\end{array}$ & In I G -a & An G-a & IV G/A -a \\
\hline 35 & walkower & $\mathrm{N}$ & IV & IV G -u/a & $\begin{array}{c}\text { IV G -u } \\
(-a)\end{array}$ & In I G -u & $\begin{array}{c}\text { An/In } \\
\text { G -u /-a }\end{array}$ & IV G -u \\
\hline 36 & algol & & - & - & I G -u- & - & - & I G -u \\
\hline 37 & casting & $\mathrm{N}$ & - & - & - & - & - & $\mathrm{G}-\mathrm{u}$ \\
\hline
\end{tabular}

\footnotetext{
${ }^{17}$ When the genitive is not given, it is assumed it ends in -a.

${ }^{18}$ If no paradign number is given it is because it was not provided.

${ }^{19}$ Probably a typographic error.

${ }^{20}$ In the genitive, the form is flamastra.

${ }^{21}$ The accusative ending is not specified, however an example is given with accusative klapsa.

${ }^{22}$ In some phrases, e.g. grać $w$ tenisa, the accusative form ends in - $a$.

${ }^{23}$ Stownik języka polskiego gives -a whereas Słownik poprawnej polszczyzny gives -u in the genitive.
} 
Hanna Mausch: Current Alternations in Inflection of Polish Masculine Inanimate Nouns in Singular...

\begin{tabular}{|c|l|c|c|c|c|c|c|c|}
\hline 38 & catering & & - & - & - & - & - & - \\
\hline 39 & cheddar & $\mathrm{N}$ & - & - & IV G -a/-u & - & In G -a & $\begin{array}{c}\text { IV G -a } \\
\text { G -a/-u }{ }^{24}\end{array}$ \\
\hline 40 & display & $\mathrm{N}$ & - & - & - & - & - & $\mathrm{G}-\mathrm{u}$ \\
\hline 41 & drajw & & IV G - ${ }^{25}$ & - & - & In I G -u & - & IV G -u \\
\hline 42 & komp & & - & - & - & - & - & - \\
\hline 43 & pulsar & $\mathrm{N}$ & - & - & - & - & - & IV G -a \\
\hline 44 & sonar & to use & - & - & - & In I G -u & - & IV G -u \\
\hline 45 & baseball & $\mathrm{N}$ & - & I G -u & I G -u & In III G -u & In G -a & I G -u \\
\hline 46 & pickup & & - & IV G -u & - & In I G -u & - & 26 \\
\hline
\end{tabular}

\subsection{Test results}

Sixteen nouns were analyzed. With the partial exception of 35 , all nouns are identified in dictionaries as inanimate. Dictionaries give $-u$ genitive endings of $1,2,37,40,44$ and 45 . Of these nouns, students assigned only $-u$ to 37 and favored it strongly in 29, 44 and 45 (over 50\% of forms given). They preferred $-a$ genitives of the other three nouns. In 16 and 31, they weakly favored $-u$ whereas in 4,35 and 43 they weakly favored $-a$. Students preferred $-a$ genitives of ten nouns (62.5\% of the 16 nouns tested for genitive forms)

Genitive forms identical to nominative / accusative (bare) forms were very rarely used.

Table 6. Students' answers: negated direct objects, direct objects after preposition do and after użyć

\begin{tabular}{|c|c|c|c|c|c|c|c|c|c|c|c|c|}
\hline No & Noun & $\mathrm{S}$ & $\begin{array}{l}\text { Dictionaries } \\
\text { based genitive } \\
\text { ending }\end{array}$ & $\varnothing$ & $(\varnothing)$ & $\mathrm{a}$ & (a) & $\begin{array}{l}\varnothing / a \\
a / \varnothing\end{array}$ & $\mathrm{u}$ & (u) & $\begin{array}{l}\varnothing / \mathrm{u} \\
\mathrm{u} / \varnothing\end{array}$ & $\begin{array}{l}\mathrm{u} / \mathrm{a} \\
\mathrm{a} / \mathrm{u}\end{array}$ \\
\hline 1 & smecz & $\mathrm{N}$ & $-\mathrm{u}$ & & & 19 & 1 & & 4 & & & \\
\hline 2 & kondom & $\mathrm{N}$ & $-\mathrm{u}$ & & & 22 & 2 & & 6 & & & 4 \\
\hline 4 & bestseller & $\mathrm{N}$ & $-a /-u$ & & & 16 & 4 & & 13 & 2 & & 3 \\
\hline 16 & katamaran & $\mathrm{N}$ & $-a /-u$ & 2 & & 12 & 2 & & 16 & 2 & & 1 \\
\hline 17 & keks & $\mathrm{N}$ & $-\mathrm{u} /-\mathrm{a}$ & & & 24 & & & 7 & 1 & & 1 \\
\hline 25 & skaner & $\begin{array}{l}\text { to } \\
\text { use }\end{array}$ & $-a$ & 4 & & 23 & 2 & 2 & 1 & 1 & & 2 \\
\hline 29 & terminal & do & $-\mathrm{u} /-\mathrm{a}$ & & & 3 & & & 27 & & & 2 \\
\hline 31 & tie-break & do & $-a(-u)$ & & & 9 & 1 & & 17 & 1 & & 2 \\
\hline 32 & toster & $\mathrm{N}$ & $-a$ & & & 30 & & & 2 & & & \\
\hline 35 & walkower & $\mathrm{N}$ & $-u(-a)$ & & & 17 & 1 & & 10 & & & 3 \\
\hline 37 & casting & $\mathrm{N}$ & $-\mathrm{u}$ & & & & & & 32 & & & \\
\hline 39 & cheddar & $\mathrm{N}$ & $-a(-u)$ & & 1 & 19 & & & 5 & & & 2 \\
\hline 40 & display & $\mathrm{N}$ & $-u$ & 1 & & 19 & 2 & & 3 & & & 2 \\
\hline 43 & pulsar & $\mathrm{N}$ & $-a$ & & & 11 & & & 8 & & & 4 \\
\hline 44 & sonar & $\begin{array}{l}\text { to } \\
\text { use }\end{array}$ & $-u$ & 2 & & 1 & 1 & 1 & 21 & 1 & & 1 \\
\hline 45 & baseball & $\mathrm{N}$ & $-u(-a)$ & 1 & & 7 & 2 & & 20 & & & 2 \\
\hline
\end{tabular}

Thirty nouns were analyzed. Two tested nouns have no dictionary entries, i.e. 38 and 42 , and in the case of chip (5) the dictionaries provide no information about its inflection.

Of the remaining twenty seven nouns, thirteen are animate according to dictionaries and their preferred genitive ending is $-a$. Students very strongly favored $-a$ accusatives of twelve of them, 28 being the exception (bare form, i.e. inanimate). The other fourteen nouns are inanimate according to dictionaries and thus their accusatives should be identical to nominatives. Students strongly favored the uninflected accusatives of four nouns: 8, 22, 30 and 33 and the nominative form was the only form given by students in 20 (and 38). To the remaining nine nouns listed as inanimate,

\footnotetext{
${ }^{24} \mathrm{G}-\mathrm{a} /-\mathrm{u}$ is offered in Stownik ortograficzny.

${ }^{25}$ Listed as a term used in tennis.

${ }^{26}$ Listed only in Stownik wyrazów obcych; no grammatical comments provided.
} 
students attached endings. They provided only - $a$ forms in the case of 34 and favored - $a$ forms of 3 , $9,11,13,23,36,41$ and 46 . In 5 and 42, they also favored -a.

When inanimate masculine nouns functioned as direct objects in the accusative, in 6 cases their nominative forms were the only forms, that is only $20 \%$ of 30 nouns have been interpreted as inanimate. Four nouns were grammatically both animate and inanimate $(12.5 \%)$. The remaining 20 nouns were grammatically animate $(66.65 \%)$. It follows that $80 \%$ of 30 nouns tested was judged by students to be animate or potentially animate. According to dictionaries ( 27 entries), 14 nouns, i.e. $51.8 \%$, were inanimate and 13 were animate $(44.82 \%)$. In comparison with dictionary entries, the percentage of animate and potentially animate nouns grew by nearly $30 \%$.

Table 7. Students' answers: accusative forms of direct objects

\begin{tabular}{|c|c|c|c|c|c|c|c|c|c|c|c|c|c|}
\hline No & Noun & $\mathrm{S}$ & $\begin{array}{c}\text { Dictionaries } \\
\text { based } \\
\text { paradigm }\end{array}$ & $\begin{array}{c}\text { Dictionaries } \\
\text { based } \\
\text { genitive } \\
\text { ending } \\
\end{array}$ & $\varnothing$ & $(\varnothing)$ & a & (a) & $\begin{array}{l}\varnothing / a \\
\mathrm{a} / \varnothing\end{array}$ & $\mathrm{u}$ & (u) & $\begin{array}{l}\varnothing / \mathrm{u} \\
\mathrm{u} / \varnothing\end{array}$ & $\begin{array}{l}\mathrm{u} / \mathrm{a} \\
\mathrm{a} / \mathrm{u}\end{array}$ \\
\hline 3 & airbus & & In & $-\mathrm{u} /-\mathrm{a}$ & 9 & 1 & 20 & & 1 & & & & \\
\hline 5 & chip & & $?$ & $-a$ & 8 & & 22 & 2 & 1 & & & & \\
\hline 6 & drink & & An & $-a$ & & & 32 & & & & & & \\
\hline 7 & kolt & & An & $-\mathrm{a}$ & 2 & & 22 & & 4 & & & & \\
\hline 8 & flamaster $^{27}$ & & In & $-a$ & 26 & & 3 & 2 & 3 & & & & \\
\hline 9 & flesz & & In & $-a /-u$ & 8 & & 20 & 1 & 1 & & & & \\
\hline 10 & ful & & An & $-a$ & 1 & & 28 & 1 & & 1 & & & \\
\hline 11 & grill & & In & $-a$ & 5 & & 24 & 1 & 3 & & & & \\
\hline 12 & hamburger & & An & $-a$ & & & 32 & & & & & & \\
\hline 13 & gokart & & In & $-a(-u)$ & 1 & & 29 & & & & & & \\
\hline 14 & grejpfrut & & An & $-a$ & 1 & 1 & 31 & 1 & & & & & \\
\hline 15 & jeep & & An & $-a$ & & & 32 & & & & & & \\
\hline 18 & klaps & & An & $-a(-u)$ & & & 32 & & & & & & \\
\hline 19 & krakers & & An & $-a$ & & & 32 & & & & & & \\
\hline 20 & laser & & In & $-a$ & 32 & & & & & & & & \\
\hline 21 & poker & & An & $-a$ & 3 & & 28 & 1 & 1 & & & & \\
\hline 22 & replay & & In & $-a /-u$ & 26 & 2 & 5 & 2 & & & & & \\
\hline 23 & sedan & & In & $-a /-u$ & 3 & & 28 & 1 & & & & & \\
\hline 24 & set & & An & $-a$ & 3 & 2 & 28 & 2 & & & & & \\
\hline 26 & squash & & An & $-a$ & 1 & & 29 & 1 & 1 & & & & \\
\hline 27 & szlem & & An & $-a(-u)$ & 5 & & 20 & 1 & & & & & \\
\hline 28 & tenis & & An & $-a$ & 21 & 1 & 11 & 3 & & & & & \\
\hline 30 & thriller & & In & $-a$ & 25 & 1 & 5 & 3 & 2 & & & & \\
\hline 33 & tuner & & In & $-a$ & 26 & & 5 & 2 & & & & & \\
\hline 34 & walkman & & In & $-a$ & & & 32 & & & & & & \\
\hline 36 & algol & & In & $-\mathrm{u}$ & 1 & & 10 & & 1 & & & & 1 \\
\hline 38 & catering & & - & - & 32 & & & & & & & & \\
\hline 41 & drajw & & In & $-\mathrm{u}$ & 6 & 1 & 20 & & 1 & & & & \\
\hline 42 & komp & & - & - & & & 25 & & 1 & & & & \\
\hline 46 & pikup & & In & $-u$ & 1 & & 30 & & & & & & \\
\hline
\end{tabular}

\footnotetext{
${ }^{27}$ In the genitive, the form is flamastra.
} 
Hanna Mausch: Current Alternations in Inflection of Polish Masculine Inanimate Nouns in Singular...

\section{Analysis}

\subsection{Phonology}

In the tables below, nouns are grouped according to their offsets following group descriptions offered by Doroszewski in SPP.

Tables 8 and 9. Nouns grouped according to their offsets

\begin{tabular}{|c|c|c|c|c|c|c|c|c|}
\hline & & & & & I & II & III & IV \\
\hline & & & & & $\begin{array}{c}\langle\dot{c}, \mathrm{~d} z \dot{z}, \mathrm{j}, \mathrm{n}, \mathrm{s}, \mathrm{z}\rangle, \\
<\mathrm{l}> \\
\langle\mathrm{p}, \mathrm{b}, \mathrm{m}, \mathrm{w}>\end{array}$ & $\begin{array}{c}<\mathrm{c}, \mathrm{cz}, \mathrm{dz}, \mathrm{d} \dot{\mathrm{z}}, \mathrm{rz}, \mathrm{sz}, \\
\dot{\mathrm{z}}>\end{array}$ & $\langle\mathrm{k}, \mathrm{g}, \mathrm{ch}\rangle$ & $\begin{array}{c}\langle\mathrm{b}, \mathrm{d}, \mathrm{t}, \mathrm{m}, \mathrm{n}, \mathrm{p}, \mathrm{r}, \mathrm{s}, \\
\quad \mathrm{t}, \mathrm{w}, \mathrm{z}>\end{array}$ \\
\hline No & $\mathrm{D}$ & $\begin{array}{l}D \\
G\end{array}$ & $\mathrm{a}$ & $\mathrm{u}$ & & & & \\
\hline 1 & In & $-\mathrm{u}$ & $\mathrm{x}$ & & & smecz & & \\
\hline 2 & In & $-u$ & $\mathrm{x}$ & & & & & kondom \\
\hline 4 & In & $-a /-u$ & $\mathbf{x}$ & $\mathrm{x}$ & & & & bestseller \\
\hline 16 & In & $-a /-u$ & $\mathrm{x}$ & $\mathbf{x}$ & & & & katamaran \\
\hline 17 & In & $-\mathrm{u} /-\mathrm{a}$ & $\mathrm{x}$ & & & & & keks \\
\hline 25 & In & $-a$ & $\mathrm{x}$ & & & & & skaner \\
\hline 29 & In & $-\mathrm{u} /-\mathrm{a}$ & & $\mathrm{x}$ & terminal & & & \\
\hline 31 & In & $\begin{array}{c}-a \\
(-u)\end{array}$ & $\mathrm{x}$ & $\mathbf{x}$ & & & tie-break & \\
\hline 32 & In & $-a$ & $\mathrm{x}$ & & & & & toster \\
\hline 35 & In & $\begin{array}{c}-u \\
(-a)\end{array}$ & $\mathbf{x}$ & $\mathrm{x}$ & & & & walkower \\
\hline 37 & - & $-\mathrm{u}$ & & $\mathrm{x}$ & & & casting & \\
\hline 39 & In & $\begin{array}{c}-\mathrm{a} \\
(-\mathrm{u})\end{array}$ & $\mathrm{x}$ & & & & & cheddar \\
\hline 40 & - & $-\mathrm{u}$ & $\mathrm{x}$ & & display $^{28}$ & & & \\
\hline 43 & - & $-a$ & $\mathbf{x}$ & $\mathrm{x}$ & & & & pulsar \\
\hline 44 & In & $-u$ & & $\mathbf{x}$ & & & & sonar \\
\hline 45 & In & $\begin{array}{c}-\mathrm{u} \\
(-\mathrm{a})\end{array}$ & $\mathrm{x}$ & $\mathbf{x}$ & baseball & & & \\
\hline
\end{tabular}

\begin{tabular}{|c|c|c|c|c|c|c|c|c|c|}
\hline & & & $\varnothing$ & $\mathrm{a}$ & $\mathrm{u}$ & $\mathrm{I}$ & II & III & IV \\
\hline 3 & In & $-u /-a$ & $\mathrm{x}$ & $\mathbf{x}$ & & & & & airbus \\
\hline 5 & $?$ & $-\mathrm{a}$ & $\mathrm{x}$ & $\mathbf{x}$ & & & & & chip \\
\hline 6 & An & $-\mathrm{a}$ & & $\mathrm{x}$ & & & & drink & \\
\hline 7 & An & $-a$ & & $\mathrm{x}$ & & & & & kolt \\
\hline 8 & In & $-\mathrm{a}$ & $\mathrm{x}$ & & & & & & flamaster \\
\hline 9 & In & $-a /-u$ & $\mathrm{x}$ & $\mathbf{x}$ & & & flesz & & \\
\hline 10 & $\mathrm{An}$ & $-\mathrm{a}$ & & $\mathrm{x}$ & & ful & & & \\
\hline 11 & In & $-\mathrm{a}$ & & $\mathrm{x}$ & & grill & & & \\
\hline 12 & An & $-\mathrm{a}$ & & $\mathrm{x}$ & & & & & hamburger \\
\hline 13 & In & $\begin{array}{c}-\mathrm{a} \\
(-\mathrm{u})\end{array}$ & & $\mathrm{x}$ & & & & & gokart \\
\hline 14 & $\mathrm{An}$ & $-\mathrm{a}$ & & $\mathrm{x}$ & & & & & grejpfrut \\
\hline 15 & An & $-\mathrm{a}$ & & $\mathrm{x}$ & & & & & jeep \\
\hline 18 & An & $\begin{array}{c}-\mathrm{a} \\
(-\mathrm{u})\end{array}$ & & $\mathrm{x}$ & & & & & klaps \\
\hline 19 & An & $-a$ & & $\mathrm{x}$ & & & & & krakers \\
\hline 20 & In & $-\mathrm{a}$ & $\mathrm{x}$ & & & & & & laser \\
\hline 21 & An & $-\mathrm{a}$ & & $\mathrm{x}$ & & & & & poker \\
\hline 22 & In & $-a /-u$ & $\mathrm{x}$ & & & replay & & & \\
\hline 23 & In & $-a /-u$ & & $\mathrm{x}$ & & & & & sedan \\
\hline 24 & An & $-\mathrm{a}$ & & $\mathrm{x}$ & & & & & set \\
\hline 26 & $\mathrm{An}$ & $-a$ & & $\mathrm{x}$ & & & squash $^{29}$ & & \\
\hline 27 & An & $-a$ & & $\mathrm{x}$ & & & & & szlem \\
\hline
\end{tabular}

${ }^{28}$ The pronunciation of the final letter is that of Polish $\langle\mathrm{j}\rangle$.

${ }^{29}$ The pronunciation of the final fricative is that of Polish $\langle\mathrm{sz}\rangle$. 


\begin{tabular}{|c|c|c|c|c|c|c|c|c|c|}
\hline & & $(-\mathrm{u})$ & & & & & & & \\
\hline 28 & An & $-\mathrm{a}$ & $\mathbf{x}$ & $\mathrm{x}$ & & & & & tenis \\
\hline 30 & In & $-\mathrm{a}$ & $\mathrm{x}$ & & & & & & thriller \\
\hline 33 & In & $-\mathrm{a}$ & $\mathrm{x}$ & & & & & & tuner \\
\hline 34 & In & $-\mathrm{a}$ & & $\mathrm{x}$ & & & & & \\
\hline 36 & In & $-\mathrm{u}$ & & $\mathrm{x}$ & & algol & & & catering \\
\hline 38 & - & - & $\mathrm{x}$ & & & & & & drajw \\
\hline 41 & In & $-\mathrm{u}$ & & $\mathrm{x}$ & & & & & komp \\
\hline 42 & - & - & & $\mathrm{x}$ & & & & & pikup \\
\hline 46 & In & $-\mathrm{u}$ & & $\mathrm{x}$ & & & & & \\
\hline
\end{tabular}

As the forms used in the accusative are identical to either genitive or nominative forms, if an inflected form is used in the accusative, it is identical to the genitive form.

\section{GROUP I:}

$-a$ is attached to ful (10), grill (11) and algol (36) in the accusative.

$-u$ is preferred with terminal (29) and baseball (45) in the genitive.

The preferred genitive ending of display (40) is $-a$.

The preferred accusative form of replay (22) is identical to the nominative form.

GROUP II: $-a$

The preferred genitive ending of smecz (1) is $-a$.

The preferred accusative ending of flesz (9) and squash (26) is - $a$.

\section{GROUP III}

Genitive and accusatives of nouns ending in -(in) $g$ end in $-u$ only and the same ending is the preferred form of tie-break (31) in the genitive, this preference is not strong however.

GROUP IV

In the table below, nouns are grouped according to their final consonants.

Tables 10 and 11. Nouns in group IV

\begin{tabular}{|c|c|c|c|c|l|l|l|l|l|l|l|l|}
\hline No & $\mathrm{D}$ & $\begin{array}{c}\mathrm{D} \\
\mathrm{G}\end{array}$ & $\mathrm{a}$ & $\mathrm{u}$ & Noun & $-\mathrm{m}$ & $-\mathrm{n}$ & $-\mathrm{p}$ & $-\mathrm{r}$ & $-\mathrm{s}$ & $-\mathrm{t}$ & $-\mathrm{w}$ \\
\hline 2 & $\mathrm{In}$ & $-\mathrm{u}$ & $\mathrm{x}$ & & kondom & $\mathrm{x}$ & & & & & & \\
\hline 4 & $\mathrm{In}$ & $-\mathrm{a} /-\mathrm{u}$ & $\mathbf{x}$ & $\mathrm{x}$ & bestseller & & & & $\mathrm{x}$ & & & \\
\hline 16 & $\mathrm{In}$ & $-\mathrm{a} / \mathrm{-u}$ & $\mathrm{x}$ & $\mathbf{x}$ & katamaran & & $\mathrm{x}$ & & & & & \\
\hline 17 & $\mathrm{In}$ & $-\mathrm{u} / \mathrm{-a}$ & $\mathrm{x}$ & & keks & & & & & $\mathrm{x}$ & & \\
\hline 25 & $\mathrm{In}$ & $-\mathrm{a}$ & $\mathrm{x}$ & & skaner & & & & $\mathrm{x}$ & & & \\
\hline 32 & $\mathrm{In}$ & $-\mathrm{a}$ & $\mathrm{x}$ & & toster & & & & $\mathrm{x}$ & & & \\
\hline 35 & $\mathrm{In}$ & $-\mathrm{u}(-\mathrm{a})$ & $\mathbf{x}$ & $\mathrm{x}$ & walkower & & & & $\mathrm{x}$ & & & \\
\hline 39 & $\mathrm{In}$ & $-\mathrm{a}(-\mathrm{u})$ & $\mathrm{x}$ & & cheddar & & & & $\mathrm{x}$ & & & \\
\hline 43 & - & $-\mathrm{a}$ & $\mathbf{x}$ & $\mathrm{x}$ & pulsar & & & & $\mathrm{x}$ & & & \\
\hline 44 & $\mathrm{In}$ & $-\mathrm{u}$ & & $\mathrm{x}$ & sonar & & & & $\mathrm{x}$ & & & \\
\hline
\end{tabular}

\begin{tabular}{|c|c|c|c|c|c|c|c|c|c|c|c|c|c|}
\hline No & $\mathrm{D}$ & $\begin{array}{l}\mathrm{D} \\
\mathrm{G}\end{array}$ & $\varnothing$ & $\mathrm{a}$ & $\mathrm{u}$ & Noun & $-\mathrm{m}$ & $-n$ & $-p$ & $-\mathrm{r}$ & $-\mathrm{s}$ & $-\mathrm{t}$ & $-w$ \\
\hline 3 & In & $-\mathrm{u} /-\mathrm{a}$ & $\mathrm{x}$ & $\mathbf{x}$ & & airbus & & & & & $\mathrm{x}$ & & \\
\hline 5 & $?$ & $-\mathrm{a}$ & $\mathrm{x}$ & $\mathbf{x}$ & & chip & & & $\mathrm{x}$ & & & & \\
\hline 7 & An & $-a$ & & $\mathrm{x}$ & & kolt & & & & & & $\mathrm{x}$ & \\
\hline 8 & In & $-a$ & $\mathrm{x}$ & & & flamaster & & & & $\mathrm{x}$ & & & \\
\hline 12 & An & $-a$ & & $\mathrm{x}$ & & hamburger & & & & $\mathrm{x}$ & & & \\
\hline 13 & In & $-\mathrm{a}(-\mathrm{u})$ & & $\mathrm{x}$ & & gokart & & & & & & $\mathrm{x}$ & \\
\hline 14 & $\mathrm{An}$ & $-a$ & & $\mathrm{x}$ & & grejpfrut & & & & & & $\mathrm{x}$ & \\
\hline 15 & An & $-a$ & & $\mathrm{x}$ & & jeep & & & $\mathrm{x}$ & & & & \\
\hline
\end{tabular}


Hanna Mausch: Current Alternations in Inflection of Polish Masculine Inanimate Nouns in Singular...

\begin{tabular}{|c|c|c|c|c|c|c|c|c|c|c|c|c|}
\hline 18 & An & $-a(-u)$ & & $\mathrm{x}$ & klaps & & & & & $\mathrm{x}$ & & \\
\hline 19 & An & $-a$ & & $\mathrm{x}$ & krakers & & & & & $\mathrm{x}$ & & \\
\hline 20 & In & $-a$ & $\mathrm{x}$ & & laser & & & & $\mathrm{x}$ & & & \\
\hline 21 & An & $-a$ & & $\mathrm{x}$ & poker & & & & $\mathrm{x}$ & & & \\
\hline 23 & In & $-a /-u$ & & $\mathrm{x}$ & sedan & & $\mathrm{x}$ & & & & & \\
\hline 24 & An & $-a$ & & $\mathrm{x}$ & set & & & & & & $\mathrm{x}$ & \\
\hline 27 & An & $-a(-u)$ & & $\mathrm{x}$ & szlem & $\mathrm{x}$ & & & & & & \\
\hline 28 & An & $-a$ & $\mathbf{x}$ & $\mathrm{x}$ & tenis & & & & & $\mathrm{x}$ & & \\
\hline 30 & In & $-a$ & $\mathrm{x}$ & & thriller & & & & $\mathrm{x}$ & & & \\
\hline 33 & In & $-a$ & $\mathrm{x}$ & & tuner & & & & $\mathrm{x}$ & & & \\
\hline 34 & In & $-\mathrm{a}$ & & $\mathrm{x}$ & walkman & & $\mathrm{x}$ & & & & & \\
\hline 41 & In & $-\mathrm{u}$ & & $\mathrm{x}$ & drajw & & & & & & & $\mathrm{x}$ \\
\hline 42 & - & - & & $\mathrm{x}$ & komp & & & $\mathrm{x}$ & & & & \\
\hline 46 & In & $-\mathrm{u}$ & & $\mathrm{x}$ & pikup & & & $\mathrm{x}$ & & & & \\
\hline
\end{tabular}

$-\mathrm{m}$

The preferred genitive ending of kondom (2) and the accusative ending of szlem ((27) is $-a$. $-n$

Both $-u$ and $-a$ forms of katamaran (16) are used in the genitive, $-u$ being slightly favored. The $-a$ accusative of sedan (23) is strongly favored and is the only accusative form of walkman (34).

$-\mathrm{p}$

The preferred accusative ending of all these nouns is $-a$.

$-\mathrm{r}$

The genitive ending - $a$ of pulsar (43) is slightly favored over - $u$; it is also the favored genitive form of walkower (35) and the strongly favored genitive form of toster (32), cheddar (39) and skaner (25).

The strongly favored genitive ending of sonar (44) is $-u$.

The accusative ending $-a$ is the only form of hamburger (12) and the strongly favored form of poker (21).

Accusatives identical with nominatives are strongly favored in the case of flamaster (8), thriller (30) and tuner (33). In the case of laser (20), only the nominative form is used.

$-\mathrm{s}$

The strongly favored genitive form of keks (17) ends in $-a$. In the accusative, $-a$ is the strongly favored ending of airbus (3) and the only ending of klaps (18) and krakers (19). In the case of tenis (28), the accusative / nominative syncretic form is preferred.

$-\mathrm{t}$

The strongly preferred accusative ending of all nouns is $-a$.

$-\mathrm{W}$

The strongly preferred accusative of drajw (41) is $-a$.

\section{- Regularities}

\section{GROUP I}

Both $-a$ and $-u$ are used in the genitive. Genitive / accusative syncretism occurs.

\section{GROUP II}

The genitive ends in $-a$. Genitive / accusative syncretism occurs.

\section{GROUP III}

The genitive ending of nouns ending in $\langle-(\mathrm{in}) \mathrm{g}\rangle$ is $-u$ and their accusative is uninflected.

\section{GROUP IV}

Accusative / genitive syncretism $(-a)$ occurs with nouns that end in $\langle-\mathrm{k}\rangle$.

Both $-a$ and $-u$ genitives occur. Genitive - accusative syncretism occurs.

The only regularity observed (and confirmed by author's other observations) is that nouns ending in <-ing> (GROUP III) have $-u$ genitives and uninflected accusatives. This, however, does not necessarily refer to other borrowed nouns ending in $\langle-\mathrm{g}\rangle$. Soft and functionally soft offsets do not 
determine the choice of case endings. Neither English nor Polish spelling of the nouns influences the choice of endings.

\subsection{Meanings}

An attempt was made to assign the tested nouns to groups other than borrowings identified by Klemensiewicz, Doroszewski and Grzegorczykowa. It turned out that the groupings and their names or descriptions offered are imprecise enough to make this assignment troublesome and subjective. Some nouns could be assigned to more than one group.

Of $-u$ genitives, nouns ending in <-ing> refer to activities and were indeed assigned $-u$ in the genitive. Replay (22 In) and display (40 In) also refer to activities but less straightforwardly. The preferred genitive of 40 was $-a$ and the preferred accusative of 22 was that of the nominative.

Endings of uncountable nouns: cheddar (39), baseball (45), poker (21), squash (26), tenis (28), algol (36) (and keks (17)) $)^{30}$ vary and no pattern has been observed.

A number of nouns tested can be considered to be names of tools or nomina intrumenti that are likely to have - $a$ genitives. These are toster (32), chip (5), flesz (9), grill (11), laser (20), skaner (25), tuner (33), walkman (34), drajw (41), komp (42), sonar (44) and possibly chip (5). All of them are identified as inanimate in dictionaries except for 5 . Most of them were assigned $-a$ genitives and accusatives. Exceptions were 20 and 26 whose preferred accusatives were identical to nominatives and 44 whose preferred genitive was $-u$.

Among the tested nouns some are names of games that should have -a genitives and accusatives. These are baseball (45, In), poker (21), squash (26) and tenis (28). Interestingly, however, in the case of 21, students preferred the uninflected accusative. Some nouns are terms used in sports. These are smecz (1 In), tie-break (31 In) and ful (10 An), set (24 An), szlem (27 An) $)^{31}$ and walkower $(35 \mathrm{In})$. Their preferred genitives and accusatives ended in - $a$, except for 31 ( $-u$ genitive) and 23 (uninflected accusative).

Several nouns denoting cars or brands were assigned - $a$ genitives: gokart (13 In), jeep (15 An), sedan (23 In) and pikup (46 In). In the accusative this ending was preferred by students as well although only 15 is animate according to dictionaries. Airbus (3 In) and kolt (7) are another brand names and their preferred accusatives ended in -a. Flamaster (8 In) is not recognized as a brand name and its preferred accusative was the same as its nominative.

Among the tested nouns are nouns denoting food: keks (17 In), cheddar (39 In), drink (6 An), hamburger (12 An), grejpfrut (14 An) and krakers (19 An) and their preferred genitives and accusatives ended in $-a$. This group of nouns can be linked to "mushrooms" and "fruits" identified by Doroszewski and "mushrooms" identified by Grzegorczykowa.

Two nouns denote books or films: bestseller (4 In) and thriller (30 In). The preferred genitive ending of 4 was $-a$. The preferred accusative of 30 was uninflected.

The remaining nouns do not belong to any meaning group: kondom (2 In), katamaran (16 In), klaps (18), terminal (29 In) and pulsar (43 In).

\section{- Regularities}

It was confirmed that nouns referring to activities are inanimate $(A c c=N o m)$. However their genitives end in $-u$ only after <-ing>.

The preferred genitive and accusative ending of nouns that are names of cars and/or brands is $-a$ if they are recognized as such.

A group of nouns referring to food has been distinguished and their preferred and sometimes only genitive and accusative ending is $-a$.

\footnotetext{
${ }^{30}$ Keks (17) may be used in reference to a biscuit and thus is both a countable and uncountable noun.

${ }^{31}$ It was assumed that hardly any student would be competent in tennis enough to identify drajw (41) with tennnis.
} 


\subsection{Context: The Verb}

All nouns, except for the ones that followed $d o$, functioned as direct objects but they followed various verbs and verb forms.

In 29 and 44, direct objects followed infinitives and the preferred noun forms ended in $-u$.

Some verbs have been used more than once.

Forms used after "to see" varied $(1,3,13,16,20,40)$.

The preferred accusative forms used after "to watch" were identical to nominatives $(22,30)$.

Forms used after "to give/to fetch" varied $(5,8,11,18,33)$.

The preferred genitive and accusative form used after "to have" ended in - $a(2,9,10,32,34$, $39,41,42$ ). This was also the preferred genitive ending of $17^{32}$.

The preferred genitive form used after "to reach/ to come to" ended in $-u(29,31)$.

Genitive forms used after "to be" varied $(35,37)$.

Genitive and accusative forms used after "to like" varied $(21,26,28,45)$.

Genitive forms used after "to use" varied $(25,44)$.

Nouns used after "to want" and "to eat" refer to food and their preferred accusative ending is $-a(6,19$ and 12,14$)$.

Nouns that follow "to buy" are names of cars/brands and their preferred accusative endin is - $a$ $(15,23,46)$.

Some sentences with the tested nouns are statements, some are questions and orders. In orders, genitive forms were used. The data, however, are insufficient to draw any conclusions.

\section{- Regularities}

If any regularities can be observed these are the preference to use $-u$ genitives and accusatives after infinitives and $d o$ (after verbs meaning "to reach/ to come to"), the preference to use accusatives identical to nominatives after "to watch" and the preference to use - $a$ genitives and accusatives after "to have".

\section{Conclusions}

Regularities observed above are listed next to the tested nouns in the table below. In the dictionary entry column, genitive endings of inanimate nouns and genitive/accusative endings of animate nouns are listed.

Table 12. Regularities

\begin{tabular}{|c|c|c|c|c|c|c|c|}
\hline No & Noun & $\mathrm{S}$ & $\begin{array}{l}\text { Dictionary } \\
\text { entry }\end{array}$ & $\begin{array}{l}\text { Ending } \\
\text { preferred }\end{array}$ & Phonology & Meaning & $\begin{array}{c}\text { Context: } \\
\text { verb }\end{array}$ \\
\hline 1 & smecz & $\mathrm{N}$ & In $-\mathrm{u}$ & $-a$ & & & \\
\hline 2 & kondom & $\mathrm{N}$ & In $-\mathrm{u}$ & $-\mathrm{a}$ & & & to have -a \\
\hline 3 & airbus & & In $-a /-u$ & An -a & & brand -a & \\
\hline 4 & bestseller & $\mathrm{N}$ & In $-\mathrm{a}(-\mathrm{u})$ & $-a /-u$ & & & \\
\hline 5 & chip & & An -a & An -a & & & \\
\hline 6 & drink & & An -a & An -a & & food $-a$ & (to want) $-\mathrm{a}$ \\
\hline 7 & kolt & & An -a & An -a & & brand $-\mathrm{a}$ & \\
\hline 8 & flamaster $^{33}$ & & In $-\mathrm{a}$ & In $-\varnothing$ & & & \\
\hline 9 & flesz & & In $-a /-u$ & An -a & & & to have -a \\
\hline 10 & ful & & An -a & An -a & & & \\
\hline 11 & grill & & In $-\mathrm{a}$ & An -a & & & \\
\hline 12 & hamburger & & An -a & An -a & & food $-a$ & (to eat) $-\mathrm{a}$ \\
\hline 13 & gokart & & In $-\mathrm{a}$ & An -a & & car -a & \\
\hline 14 & grejpfrut & & An -a & An -a & & food $-a$ & (to eat) $-\mathrm{a}$ \\
\hline 15 & jeep & & An -a & An -a & & car/brand -a & (to buy) $-\mathrm{a}$ \\
\hline 16 & katamaran & $\mathrm{N}$ & In $-\mathrm{a} /-\mathrm{u}$ & $-u /-a$ & & & \\
\hline 17 & keks & $\mathrm{N}$ & In $-a /-u$ & $-a$ & & food $-a$ & to have $-\mathrm{a}$ \\
\hline
\end{tabular}

\footnotetext{
${ }^{32}$ In Polish nie ma means "there is no".

${ }^{33}$ In the genitive, the form is flamastra.
} 


\begin{tabular}{|c|c|c|c|c|c|c|c|}
\hline 18 & klaps & & An -a & An -a & & & \\
\hline 19 & krakers & & An -a & An -a & & food $-a$ & (to want) $-\mathrm{a}$ \\
\hline 20 & laser & & In -a & In $-\varnothing$ & & & \\
\hline 21 & poker & & An -a & An -a & & & \\
\hline 22 & replay & & In $-\mathrm{a} /-\mathrm{u}$ & In $-\varnothing$ & & (activity) In & $\begin{array}{l}\text { to watch } \\
\text { Acc - } \varnothing\end{array}$ \\
\hline 23 & sedan & & In $-\mathrm{u}$ & An -a & & car -a & (to buy) -a \\
\hline 24 & set & & An -a & An -a & & & \\
\hline 25 & skaner & $\begin{array}{l}\text { to } \\
\text { use }\end{array}$ & In $-\mathrm{a}$ & $-a$ & & & \\
\hline 26 & squash & & An -a & An -a & & & \\
\hline 27 & szlem & & An $-\mathrm{a}(-\mathrm{u})$ & An -a & & & \\
\hline 28 & tenis & & An -a & In/An -Ø/-a & & & \\
\hline 29 & terminal & do & In $-\mathrm{u} /-\mathrm{a}$ & $-\mathrm{u}$ & & & $\begin{array}{l}\text { infinitive }-\mathrm{u} \\
\text { to reach/to } \\
\text { come to -u }\end{array}$ \\
\hline 30 & thriller & & In $-\mathrm{a}$ & In $-\varnothing$ & & & $\begin{array}{c}\text { to watch } \\
\text { Acc }-\varnothing\end{array}$ \\
\hline 31 & tie-break & do & In $-\mathrm{a}(-\mathrm{u})$ & $-u /-a$ & & & $\begin{array}{l}\text { to reach/to } \\
\text { come to -u }\end{array}$ \\
\hline 32 & toster & $\mathrm{N}$ & In $-\mathrm{a}$ & $-\mathrm{a}$ & & & to have $-\mathrm{a}$ \\
\hline 33 & tuner & & In $-\mathrm{a}$ & In $-\varnothing$ & & & \\
\hline 34 & walkman & & In $-\mathrm{a}$ & An -a & & & to have -a \\
\hline 35 & walkower & $\mathrm{N}$ & In -u (a) & $-a /-u$ & & & \\
\hline 36 & algol & & In $-\mathrm{u}$ & An -a & & & \\
\hline 37 & casting & $\mathrm{N}$ & In $-\mathrm{u}$ & $-\mathrm{u}$ & -ing $+u$ & activity In $-\mathrm{u}$ & \\
\hline 38 & catering & & - & In -Ø & -ing $+\varnothing$ & activity In - & \\
\hline 39 & cheddar & $\mathrm{N}$ & In $-\mathrm{a}(-\mathrm{u})$ & $-\mathrm{a}$ & & food $-\mathrm{a}$ & to have $-\mathrm{a}$ \\
\hline 40 & display & $\mathrm{N}$ & - & $-\mathrm{a}$ & & (activity) In & \\
\hline 41 & drajw & & In $-\mathrm{u}$ & An -a & & & to have $-\mathrm{a}$ \\
\hline 42 & komp & & - & An -a & & & to have -a \\
\hline 43 & pulsar & $\mathrm{N}$ & In $-\mathrm{a}$ & $-a /-u$ & & & \\
\hline 44 & sonar & $\begin{array}{l}\text { to } \\
\text { use }\end{array}$ & In $-\mathrm{u}$ & $-\mathrm{u}$ & & & infinitive $-\mathrm{u}$ \\
\hline 45 & baseball & $\mathrm{N}$ & In $-\mathrm{u}$ & $-\mathrm{u}$ & & & \\
\hline 46 & pikup & & In $-\mathrm{u}$ & An -a & & car -a & (to buy) $-\mathrm{a}$ \\
\hline
\end{tabular}

Even though the number of nouns tested was only 46, some conclusions can be offered and the first one is that very few regularities have been observed.

Phonological conditioning of endings has not been found, i.e. the offsets do not condition the choice of endings. Nouns ending in <-ing> refer to activities, are inanimate and end in -u in the genitive. In their case either the meaning or the formant -ing can condition the choice of endings.

The meaning of nouns is important in the case of food and cars/brands. These nouns are interpreted as animate and take -a in the genitive and accusative.

Nouns used in the context of "to have" tend to be interpreted as animate and their preferred genitive and accusative ending is -a. This may also be the preferred form of nouns used in the context of "to want".

The results demonstrate that among borrowings the number of "grammatically" inanimate nouns is small and a huge majority of nouns are interpreted as "grammatically" animate or potentially animate. All genitive and genitive/accusative forms considered, the preferred ending of 35 nouns was -a which amounts to $76 \%$. Thus -a was the preferred genitive ending of three fourths of the nouns tested. Contrary to descriptions in the books consulted, genitives in -u are used very rarely with borrowed nouns.

As it appears, relative frequency of the nouns has no real impact on the choice of endings. With less frequently used nouns including "technical" terms, however, students' preference of -a agenitives and accusatives was weaker.

Since new words tend to follow the most productive patterns, it follows that the animate masculine paradigms are productive in Polish. 
Hanna Mausch: Current Alternations in Inflection of Polish Masculine Inanimate Nouns in Singular...

In conclusion, borrowed masculine inanimate nouns are increasingly interpreted as grammatically animate and in most cases this interpretation is arbitrary. Hence the term "facultative animacy" has not been used here as it may imply conscious awareness and meaningful manipulation of case forms.

Of the dictionaries consulted, ISJP most closely reflects the current usage of case forms.

\section{References}

Bańko M. (Ed.) 2000. Inny Stownik Języka Polskiego PWN [A Different Dictionary of the Polish Language PWN], Warsaw: PWN.

Doroszewski W. (Ed.) 1980. Stownik poprawnej polszczyzny [Dictionary of correct Polish], Warsaw: PWN

Grzegorczykowa R., Laskowski R., Wróbel H. (Eds.) 1998. Gramatyka wspótczesnego języka polskiego: Morfologia [Grammar of modern Polish: Morphology], Warsaw: PWN.

Klemesiewicz Z. 1962 [1981]. Podstawowe wiadomości z gramatyki języka polskiego [Essentials of Polish grammar], Warsaw: PWN.

Klemensiewicz Z., Lehr-Spławiński T., Urbańczyk S. (Eds.) 1981. Gramatyka historyczna języka polskiego [Historical grammar of the Polish language], Warsaw: PWN

Markowski, A. (ed.) 1999. Nowy stownik poprawnej polszczyzny [New dictionary of the correct Polish], Warsaw: PWN.

Skorupka S., Auderska H., Łempicka Z. (Eds.) 1968. Mały słownik języka polskiego [Small dictionary of the Polish language], Warsaw: PWN.

1998. Stownik wspótczesnego jezzyka polskiego [Dictionary of contemporary Polish language], Warsaw: Przegląd, Reader's Digest.

2002. Stowniki PWN, CD version 1.1: Stownik języka polskiego, Stownik ortograficzny, Stownik wyrazów obcych, Stownik poprawnej polszczyzny, [Dictionaries PWN: Dictionary of Polish language, Spelling dictionary, Dictionary of foreign words, Dictionary of proper Polish], Warsaw: Wydawnictwo Naukowe PWN. 